\title{
Eesti spordikommentaatorite ütlused rahvahuumori allikana
}

\author{
PIRET VOOLAID, KALLE VOOLAID
}

Spordiülekandeid kommenteerivate ajakirjanike - spordikommentaatorite - töö on tähelepanuväärne kogu maailmas. Põhja-Ameerikas näiteks võivad mõjukamad neist pääseda valdkondlikku kuulsuste halli (Sports Broadcasting Hall of Fame), Venemaal on aga loodud assotsiatsioon (Российская ассоциация спортивных комментаторов), mis on muuhulgas seadnud eesmärgiks uute kommentaatorite koolitamise (vt nt Kalenjuk 2019: 8).

Spordikommentaatorite lennukas keeleloome mõjub ehedalt ja sageli humoorikalt, mistõttu on nende naljakate ütluste ülestähendamisest saanud pärimuse kogumise valdkond. Mujal maailmas on ilmunud otsereportaažide tsitaatide kogumikke (nt Brady 2012), Eestis on ütlusi samuti kogutud ja trükis avaldatud (nt Rebane, Tammaru 2010; Voolaid, K. 2010, 2015). Spordiajakirjanike keelekasutust kui eraldi registrit on uuritud eri vaatenurkadest, näiteks populaarsemate spordialade lõikes (vt Ferguson 1983; Müller 2007; eesti jalgpallikommentaatorite poeetilisest keelest Susi 2019 jne), vähesel määral on seejuures esile toodud huumori aspekti (nt Chovanec 2016).

Spordikommentaatorite naljakaid ütlusi saab määratleda folkloorina: see on spordikogukonda siduv meelelahutus, rahvahuumor, mis hakkab pärast käibele tulekut oma elu elama spordiringkondades, ent vahetevahel laiemaltki, nii et see võib kaotada sideme loojaga.

Artiklis analüüsime nii siinsetes spordiringkondades kui ka lihtsalt spordisõprade hulgas populaarset huumorivormi - spordireporterite otse-eetri ütlusi ehk tsitaate ehk kilde ${ }^{1}$-, mis levib tänapäeval eeskätt internetikanalite (nt sotsiaalmeedia) kaudu, ent mille põhjalikumad käsitlused eesti ainese kohta puuduvad.

Tsitaate võib seostada konkreetsete ajakirjanikega: näiteks legendaarselt Suurbritannia kommentaatorilt David Robert Colemanilt pärit ütlused tõid käibele tänini tuntud termini Colemanballs (sariväljaanne „Private Eye's Colemanballs” on ilmunud alates 1982. aastast), palju tsiteeritud on ka vormel 1 võistlussarja Suurbritannia kommentaatori Murray Walkeri omalaadsed ja sageli naljakana mõjuvad ütlemised Murrayisms (Williams-Smith 2019). Mõlema termini elujõu kinnituseks levivad sotsiaalmeedias teemaviited \#colemanballs ja \#murrayisms. Eesti meediaski on siinseal koostatud ajakirjanike naljakate/parimate väljaütlemiste edetabeleid ning folklooriks on muutunud legendaarsete spordikommentaatorite Gunnar Hololei, Toomas Uba (ubaismid), Lembitu Kuuse, Tiit Räägu, Tarmo Tiisleri jt ütlused. Praeguse

\footnotetext{
${ }^{1}$ Kasutame kõnealuse naljamaterjali kohta neutraalset mõistet ütlused, mille ühe allosa moodustavad häired ja apsud (ingl bloopers; gaffes), kuid mahlakas väljenduslaad, mida saab pidada huumoriks, on vigasest keelest sageli väga kaugel.
} 
aja üks populaarsemaid kommentaatoreid on Kalev Kruus, kelle mahlakaid väljaütlemisi talletab koguni kaks Facebooki gruppi: Kalev Kruusi parimad palad (13 500 jälgijat ${ }^{2}$ ) ja Kalev Kruus tsitaadid (9500 jälgijat). Jälgijate suur hulk ei tähenda alati tsitaatide aktiivset levikut, kuid näitab elavat huvi teema vastu.

Siinse uurimuse eesmärk on teha sissevaade Kalle Voolaidi kogutud materjali. Tähelepanu keskmes on küsimus, millistel huumoriteoreetilistel mehhanismidel ütlused põhinevad ja milliste seaduspärade alusel saab kirjapandut süstematiseerida või kategoriseerida.

\section{Materjal ja meetod}

Analüüsitav aines on Kalle Voolaidi aastatel 2010-2019 koostatud tsitaadikogu, mis sisaldab üle 2000 ütluse. Need on kogutud otse-eetrist, vähemal määral on talletatud rahva seas liikuvaid ning erinevates meediakanalites edastatud spordikommentaatorite naljakaid väljaütlemisi. Ligemale 95\% materjalist on eestikeelne (pisut leidub vene- ja ingliskeelseid kilde), enamasti kogutud korvpalli-, jalgpalli-, kergejõustiku-, suusatamis- ja olümpiaülekannetest, vähemal määral ka mujalt. ${ }^{3}$ Materjalikogu põhjal on koostatud kaks naljaraamatut: kogumikud „Mootorratturid tulevad kurvist, Till pikalt ees!” (Voolaid 2010) ja „Mootorratturid tulevad kurvist, Till pikalt ees! 2." (Voolaid, K. 2015). Esimeses neist leidub ka nõukogudeaegseid tsitaate, teine on komplekteeritud ainult lähiminevikus, peamiselt aastatel 2011-2015 eetris olnud eestikeelsetest võistlusülekannetest nopitud ütlustest. Siinses kirjutises on kolmandiku ulatuses arvesse võetud ka uuemat materjali, trükis seni avaldamata tsitaate. Kokku on aja jooksul tsitaate kogunenud rohkem kui 80 kommentaatorilt, kellest kümmekond ei ole eestlased ja kes on rohkem kui 90\% ulatuses meessoost. Eeskätt eetilistel põhjustel on kõik tekstid esitatud anonüümselt ilma autorite nimedeta nii artikli aluseks olnud ilmunud kogumikes (Voolaid, K. 2010, 2015) kui ka siinses kirjutises.

\footnotetext{
${ }^{2}$ Oluline on märkida, et Facebooki leht Kalev Kruusi parimad palad on seotud hasartmängufirmaga Betsafe (profiilipildil kannab Kalev Kruus firma logoga T-särki ja postituste hulgas leidub tarbijamänge, mille auhinnaks on firma suveniirid). Selles kontekstis võib „tsitaadijahti” näha turundustegevuse osana ja niisugusest vaatenurgast ei ole huumori funktsioonid süütud, vaid on tuntav siht peale pelga meelelahutuse ka kliente tarbima suunata. Teistest värvikatest spordiajakirjanikest eristuvana leidsid Kalev Kruusi tsitaadid oma nimelise koha ka Eesti Spordija Olümpiamuuseumi 2017. aastal avatud pallimängunäitusel „Kõik mängu!”.

${ }^{3}$ Materjal kajastab ainult spordiajakirjanike ülekannete suuliste kommentaaride väljanoppeid, kõrvale on jäänud nt sportlastega tehtud intervjuud, millest välja korjatud tsitaadid moodustavad huumori omaette elujõulise allvormi. Nt Soome suusahüppaja Matti Nykänen on nii Soome kui ka Eesti folkloori rikastanud paljude tsitaatidega (tuntuim neist on kindlasti Elämä on laiffi, vt ka Delfi Sport 2019). Paljuski põhinevad need ütlused samadel võtetel, naljakatel truismidel või vastuoludel.

${ }^{4}$ Neile kogumikele andis nime 1970. aastatest pärinev ja folkloorsesse käibesse läinud võidusõidukommentaar, kus kahemõttelisuse põhjustab toonase tuntud mootorratturi Indrek Tilli nimi.
} 
Materjal on koondatud PostgreSQL andmebaasi, mis võimaldab teha tekstiliste parameetrite lõikes päringuid ja statistilist analüüsi. Andmebaas asub Eesti Kirjandusmuuseumi folkloristika osakonna teadusarhiivis EFITA (F02-016-0001).

Materjal on kogutud soovist otsereportaažides televaatajana kogetud emotsioone ja nähtud võistluste erilisemaid hetki humoorikate ütluste kaudu hiljem veel kord läbi elada ja teistegagi jagada. Põhiliselt ühe inimese kirjapandud materjal kajastab eeskätt individuaalset huumoritaju ning võimaldab introspektiivselt uurida ennekõike seda, mis on kirjapanijale kui artikli ühele autorile naljakas tundunud. Samas kinnitab ilmunud kogumike müügiedu neis avaldatud naljade populaarsust.

Siin käsitletavat ainest on võimalik jaotada võistluste põhjal (selgelt eristuv on nt olümpiatemaatika), spordialade põhjal, reporteritöö eripärast lähtudes (nt reportaaže alustades tehtud apsakad, tele- ja raadiotöö eripära mittearvestamine jm) või veel mitmel muul moel. Nii mõndagi neist liigitustest on kasutatud ka eespool nimetatud kogumikes (Voolaid, K. 2010, 2015).

Käsitleme spordikommentaatorite otse-eetri ütlusi kui omalaadset folkloori ja keelt ühendavat lühivormi ning analüüsime ainest huumoriteoreetilisest vaatenurgast. Artikli keskmes on pigem keeleliste vahendite roll tsitaatide naljakana mõjumisel, st esteetilised ja/või poeetilised lingvistilised aspektid, millega kaasneb huumor. Liigituse eri alustel esitatud alamkategooriad võivad kattuda. Tekstilise materjali kogumisspetsiifikast tulenevalt jäävad tähelepanu alt välja mnemotehnilised vahendid, millega nalja esile kutsutakse, nt intonatsioon ning hääle või heliga tekitatavad humoorikad võtted, mille uurimiseks tuleks kasutada reportaažide helisalvestusi.

\section{Huumoriteoreetiline raamistus}

Kommentaatorite ütlused vormistab huumoriks/naljaks üldjuhul keegi teine, mitte nemad ise: teleülekande või spordivõistluse jälgija või keegi, kes on sattunud emotsionaalse sündmuse tunnistajaks. Ütlused on kuulja ja kirjapanija jaoks enamasti meelelahutuslike funktsioonidega spontaanne $\mathrm{e}^{5}$ ja argine situatsioonihuumor, mida kommentaator ise ei pruugi naljakana tajuda. Kuigi pärimusrühma sees on kommentaatorite isikud teada, võivad nende paremad väljaütlemised siiski anonüümsete naljadena konkreetsest spordisõprade ringist väljapoole kanduda ja edasi levida (nt huumorikogumike kaudu või anekdoodina edasi rääkides).

Sotsiaalsetele aspektidele suunatud kultuurilis-ajaloolistes naljateooriates käsitletakse huumorit kui ühiskonda peegeldavat nähtust, mille abil saab avastada vastuolusid või valupunkte ning varjatud vaateid ühiskonnas toimuvale (Laineste 2003: 798). Kommentaatorite väljaütlemised annavad aimu spordiajakirjanike mõttemaailmast ning sellest, millised on spordimaailma hetketrendid (riikide poliitilised pinged, sportlastevahelised suhted, suhtumine kohtunikesse, ausasse mängu, dopingusse jne). Ainese folkloriseerudes võivad naljakad ütlused muutuda rühma-

\footnotetext{
${ }^{5}$ Spordiülekannetele on omane enamasti ajapuudusest tulenev kirjelduse spontaanne improvisatsioon (vt Steen 2008: 152-153; Liik 2013: 12; Uba 1968: 131).
} 
pärimuseks, mis jääb aastateks pärimusrühma suulisesse kõnepruuki või kirjalikku repertuaari. Esialgse konteksti ja personaalsuse hajudes saab oluliseks just naljakas ütlus, mis eriti lühikeses vormis juurdub nt huvirühma slängi või jääb pikema narratiivina käibesse.

1960.-1970. aastatel tõusid huumoriuurimises üsna tugevasti esile nn kognitiivsed huumoriteooriad, mis lähtuvad huumorist kui tunnetusega seotud kogemusest ning tuginevad sellele, et naljakas (verbaalses või mitteverbaalses) objektis endas on mingi objektiivne, „tegelik” vastuolu või ühtesobimatus (inkongruents), mis tekitabki üllatusmomendi ja naljakuse (Krikmann 2004: 6). Kommentaatorite ütlustest kui huumorist rääkides võib eristada juhuhuumorit (kukub tahtmatult naljakana välja) ja tahtlikult loodut, kuigi reportaažide vaatajal-uurijal on ilma ajakirjaniku enda selgituseta mõnigi kord raske tuvastada, kummaga on tegemist. Spordireportaaži spetsiifikast lähtudes tekivad naljad pigem juhuslikult. Tšehhi lingvist Jan Chovanec (2016: 104) on jalgpalliajakirjanike mikrofoniapsude näitel rõhutanud, et huumoriefekt sünnib otseülekannetes enamasti juhuslikult, ilma eelneva naljategemise kavatsuseta. Mikrofoniapsudes (st mikrofon on otseülekandeks sisse lülitatud, kuid reporteri teadmisel väljas, mistõttu on ta enda teadmata otse-eetris vaba tekstiga) on huumor tema sõnul seotud vääriti mõistetud osaluskontekstiga (ingl misjudged participation framework). Kui mikrofon juhtub sisse jääma, loob eetrisse jõudev reporteri telgitagune jutuajamine tahtmatu huumori efekti ja auditoorium naudib pealtkuulaja privilegeeritud rolli (Chovanec 2016). Ka otsereportaaži auditoorium naudib head reporteritööd ja võib selle spetsiifikat teades (kiire kõne ajal juhtub kõike) tihti olla juba ette naljale hälestatud. Torsten Müller (2007) on jalgpallikommentaatorite keele analüüsis rääkinud planeerimata kõnekeelest (ingl unplanned spoken language). Loomulikult ei saa pika reportaaži vältel välistada reporteri tahtlikku naljategemise taotlust.

Alleen Pace Nilsen ja Don L. F. Nilsen (2000: 6) on juhusliku huumori jaganud lingvistiliseks (verbaalseks) ja füüsiliseks. Naljakad kommentaarid kuuluvad esimeste hulka. Peale nende saame samalaadse juhuhuumori alla paigutada nt lapsesuuütlused (vt Voolaid, P. 2015), õpilastöödest (nt kirjanditest, üliõpilasuurimustest) pärinevad naljakad tsitaadid jpm. Igal allrühmal võib tuvastada universaalsed alused, mis on enamasti seotud lingvistilise ressursiga, kuid sõltuvalt nähtuse eripärast väljenduvad erinevalt. Nt suures osas lapsesuunaljades põhineb naljakana tajutu laste keeleomandamise ja -arenguga kaasnevatel keelevääratustel ning maailma tundmaõppimisega seotud originaalsetel ja omalaadsetel tõlgendustel (vt Voolaid, P. 2015: 855).

Ajakirjanike ütlusi kui sõnalist huumorit võib analüüsida Salvatore Attardo ja Victor Raskini (1991) verbaalse huumori üldteooria (ingl general theory of verbal humor) valguses, mis üldjoontes seisneb kuue teadmusressursi hierarhilises representatsioonimudelis. Teadmusressursside tasandid on lühidalt kokku võttes järgmised (vt ka Attardo 2010: 108; Krikmann 2004: 53-63).

1. Skriptide (ehk tähendusskeemide) opositsioon, mis on võetud üle Raskini (1985) varasemast semantilisest huumoriteooriast ja mille kohaselt nali peab sobima kahe eri skriptiga ning need omakorda peavad olema mingis mõttes vastandlikud. 
Spordikommentaatorite ütlustes sünnib nali enamasti nt ootuspärasest erinevate väljaütlemiste pinnalt, aga ka ootamatute kõnekujunditena jne.

2. Loogiline mehhanism, mille rikkumisel tekkivad häired ja vääranaloogiad kutsuvad esile huumori. Kiirkõnet kasutavate spordikommentaatorite väljaütlemistes tuleb tihti ette loogikahäireid ja vasturääkivusi, mis kuulajale naljakana mõjuvad.

3. Situatsioon, mis moodustab nalja kontekstuaalse alustala ning hõlmab tegevust, osalisi, objekte jm. Siinsel juhul on selleks spordivõistlus, mida otsereportaažis kirjeldatakse ja analüüsitakse.

4. Sihtmärk ehk nalja pilkeobjekt. Isikutena, kelle pihta pilge või nali on suunatud, saab konkreetses aineses eraldi välja tuua eelkõige sportlased, kuivõrd reporter ju esijoones sportlaste tegevust kommenteeribki, samuti treenerid ja kohtunikud. Nalja ajendina võivad tulla arvesse ka täiesti spordiväliste ühiskondlike valdkondadega seotud juhuslikud objektid. Juhupersoonid saavad tsitaatide kangelasteks seoses kommentaari käigus hetkeks esile kerkivate teemadega, nt päevakajaliste poliitsündmuste, geograafiliste assotsiatsioonide (võistluse toimumispaik) tõttu, samuti seoses kommentaatorite täiesti ennustamatute mõttekäikudega.

5. Narratiivne strateegia ehk žanr, milles nali töötab (nt anekdoot, vanasõna, kõnekäänd). Käesoleval juhul lühema-pikema monoloogina või dialoogina (mõnikord võivad ülekande teha kaks reporterit, kuid peale reporteri võib kommentaatorina otsestuudiosse olla kutsutud ka spordiala ekspert) esitatud napisõnalise tegevuse kirjeldusega tekstid, mis võivad kasutada konkreetseid žanre (nt vanasõna, võrdlust).

6. Keel ehk koomika tekkeks vajalikud leksikaalsed, süntaktilised, fonoloogilised jm lingvistilised valikud. Siinses kirjutises on põhirõhk eesti keele võimalustel, mis määravad nalja tekke tekstilise aluse (nt sõnavaralised, lauseehituslikud mitmemõttelisused).

Teooriat saab rakendada igale naljatekstile eraldi, kuid konkreetset ütlust tuleks analüüsida ka laiemas kultuurikontekstis (kes kellele, miks, kus, millal nalja teeb). Eesti keelenaljade analüüsimisel on Attardo ja Raskini verbaalse huumori üldteooriat varemgi kasutatud, nt käsitledes lapsesuunalju (Voolaid, P. 2015), aga ka sõnamängulist huumorit nt populaarse Facebooki grupi KalambuuR postituste näitel (vt Harrik 2020, siinsamas ajakirjas).

\section{Spordikommentaatorite ütlused kui mitmetasandiline keelekoomika}

Spordireportaažide emotsionaalne olemus on tihedalt huumoriga seotud: tugevatel tundetoonidel (võidurõõm, kaotusekibedus) on otsustav kontekstuaalne roll, et reporteri konkreetne väljaütlemine saaks üldse humoorikalt mõjuda. Seetõttu osutame analüüsiosa alguses tundevärvidele, millest naljad tõukuvad. Verbaalse huumori üldteooria paigutab kontekstuaalsed nähtused situatsiooni tasandile. Seejärel toome välja huumori tekkes esilduva loogiliste mehhanismide tasandi ja lingvistilise tasandi. 
Loogiliste mehhanismide tasand viitab vääranaloogiatele ja loogikahäiretele, mille abil sünnib huumori tekkeks vajalik mitmemõttelisus. Lingvistiline tasand väljendub eeskätt leksikaalsetes hääldusvigades, alateadlikes ehk freudilikes eksimustes (ingl Freudian slips), malapropismides (sõna asemel kasutatakse mõnd teist, lähikõlalist sõna, nt sarnaskõlaliste võõrsõnade väärkasutus), spoonerismides (metateesil põhinevad vahetatud silpide või häälikujärjenditega vormelid). Kuid see väljendub ka süntaktiliselt, nt varem olemasolevate ütluste ja kultuuritekstide humoorikas parafraseerimises.

Attardo (1994) järgi esinevad keelenaljad tavakõnes sõnamängudena, kuid ta eristab sihipäraselt tehtavaid kalambuure, mis on samuti (meta- ja luulekeelega sarnaselt) keelenaljad. Ta eristab sarnassõnamängudes paronüümiat ja homonüümiat. Paronüümid on foneemiliselt koosseisult (kõlalt) sarnased, kuid mitte identse kirjapildiga, ja kannavad eri tähendust (Nüüd tuleb vigadest óppused teha! pro óppust võtta). Homonüümid on foneemiliselt ja/või grafeemiliselt koosseisult sarnased, jagunedes homograafideks - ühtmoodi kirjapildi, kuid eri hääldusega sõnad (palk : pal'k) - ning homofoonideks - sama häälduse, aga erineva kirjapildi ja tähendusega sõnad (baar: paar).

Üks osa spordireportaažide keelenalju tekibki sarnase hääldusega sõna kasutamisest vales tähenduses, st nalja leksikaalne lõikepunkt lasub põhiliselt homonüümidel ja paronüümidel. Morfeemkoosseisu poolest osaliselt kattuvad sõnad võivad kiires suulises kõnevoos segi minna, nii et mõtte edasiandmisel kasutatakse mõnd sõna, mis assotsieerub sõnaga, mida parajasti tahetakse öelda. Huumori tekkeks piisab sõna tähendust muutvast täheasendusest, sest ütluste kuulja või lugeja peab kokku viima kaks skripti - selle, mille kutsus esile öeldu, sellega, mida oli mõeldud või tahetud esile kutsuda (vt ka Nilsen, Nilsen 2000: 8). Muidugi võivad kommentaatorid kasutada taotluslikke huumorivõtteid (sõnamängud, mille aluseks on spoonerism, malapropism, freudilik keelevääratus, paranomaasia), kuid pigem tekivad sellised keelelised kokkusattumused kiires reportaažis juhuslikult. Mõnikord aga sobib ütlusi kirjeldada neutraalsete lingvistiliste terminitega (metatees, paronüümia, homonüümia ning selle alatüübid homograafia ja homofoonia).

\subsection{Emotsionaalsed ja värvikad ütlused}

Emotsionaalsed väljendused on laiem tasand, mis käivitab huumori ja määrab selle tonaalsuse. Kategooriasse paigutuvad nt ehe võidurõõm, sügav kaotusekibedus, hinnang spordiareenil toimuvale, laiem suhestumine spordiga. Niisugustes emotsionaalsetes pursetes avaldub tihtipeale avalikkusega jagamiseks ehk isegi mitte mõeldud kommentaatorite sisemaailm ja tulevad esile nende isiklikud lemmiksportlased, erilistel hetkedel vallanduvad kontrollimatult parasiitväljendid.

Materjalis avaldub ajakirjanike mahlakas kujundiloome ja efektne väljendusviis, kusjuures emotsionaalsuse suurendamise ja piltlikkuse intensiivistamise levinuim võte on unikaalsete ja originaalsete võrdluste kasutamine. Spontaanse kiirkõne käigus otse-eetris sündinud võrdlused mõjuvad eriti ehedalt ja humoorikalt. Tsitaatides kasutatud võrdluste vormitunnusteks on enamasti sidesõnad kui (2000-üksuselisest 
kogumaterjali hulgast 230 korda), nagu (110 korda; näited 1-5), vähestel juhtudel otsekui, justkui. Esindatud on samuti nagu kõnekeelne vorm nigu (näide 6). Statistiliselt on selliste vormitunnuste alusel võrdlustena kvalifitseeruvaid naljatsitaate u 350 ehk üle $20 \%$ kogu ainehulgast. ${ }^{6}$

(1) Zenjov kukkus ka, nagu oleks voodisse heitnud. Aeglaselt ja rahulikult.

(2) Mika naeratab nagu mutrivõti!

(3) Ta tormas palli järele nagu Anna Karenina rongi alla.

(4) Tere varahommikust teile kõigile seal Eestis! Küllap on virgemad spordisõbrad juba ärganud ja teie silmalaud käivad nagu laudauksed kinni-lahti.

(5) Nii nagu vanake Hottabõtšil oli habe, nii oli ka Kevin Durantil. [USA korvpallur Kevin Durant oli kasvatanud habeme, mis meenutas kommentaatorile lastekirjanduse klassikast tuntud võluri lõuakaunistust.]

(6) See on juba nigu uhamine, tead!

Tsitaatides esineb ka sõnade viisi, kombel, moodi jne abil moodustatud võrdlusi (näited 7, 8).

(7) Korraliku koduperenaise kombel koristas ta palliga väravanurgast ämblikuvõrgu ära.

(8) Mošnikovilt tuleb eemalt esimene selline pommi moodi tegevus.

Ootamatute võrdlustega võib väljendada samuti ehedat võidu- või kahjurõõmu (seda vastavalt kommentaatori vaatepunktile). Kellegi võit on võimalik üksnes teis $(t) e$ kaotus(t)e arvel ja reporter valib sageli poole (nt rahvusvahelistel võistlustel oma riigi sportlased), keda ta esindab $(9,10)$. Ehedat võidurõõmu saab edasi anda väljaütlemistega, milles on aimata kommentaatori tundelisust kiire situatsiooni kirjeldamisel $(10,11)$. Peale eheda võidurõõmu väljendavad ajakirjanikud äärmuslikke emotsioone sügava kaotusekibeduse korral, kus huumor tekibki sellest, kui tavapäratult reporter kaotusvalu verbaliseerib - teinekord piisab tavapärasest pikemast kurvastushüüdest. Erinevaid tundetoone saab näidata artikuleerimata hüüdsõnalise väljenduse kaudu (12), mis mõjuvad konkreetses olukorras ja tehniliste vahendite, eripärase intonatsiooniga või muul moel väljaöelduna naljakana. Sellistel juhtudel on emotsioonidel määrav osa huumorit käivitava kontekstuaalse tegurina: et kirjapanemise ajal naljakalt mõjunud tekstid hiljem lugedes naljakad oleksid, tuleb konkreetset olukorda meenutada või ette kujutada.

(9) Chelsea varumängijate pink särab nagu jõulupuu.

(10) Ja pikad on Valmiera meeste näod! Seda on lust vaadata, kui lätlasel on nägu pikk! [Kommentaatoril on rõõm vaadata kaotusega leppinud konkurentide pikki ehk pettunud nägusid.]

\footnotetext{
${ }^{6}$ Lingvist Katre Õim on oma uurimuses „Võrdluste struktuurist ja kujundisemantikast” kinnitanud, et võrdlused moodustavad eesti kõnekäändude hulgas mitte ainult suurima, vaid ka vormilt homogeenseima ja selgepiirilisima alaliigi (Õim 2003: 20).
} 
(11) Ja saab Kangur ründelaua! Ja saab Kangur ründelaua ja lööb küünarnukiga silma Kostas Papanikolaoule! Aga see on ainult ilus mälestus kreeklasele!

(12) Ai-ai-ai-ai-ai! Kas olete minuga nõus?

Võrdluste ilmestamiseks ja intensiivistamiseks kasutatakse mõnigi kord sobivaid näiteid päevakajalistest ja vaataja jaoks arusaadavatest teemadest, demonstreerides selliselt ühtlasi ajakirjaniku silmaringi ja hinnanguid maailmas toimuvale (13). Peale konkreetsete vormitunnuste järgi tuvastatavate võrdluste (14) on võrdlemine ütlustesse tihti kaudselt sisse kirjutatud. Levinud on pehmendamine või kaudeütlemine, mis võib mõjuda nii nalja kui ka kriitikana (15).

(13) Praegu juubeldavad Mehhiko fännid nii, nagu oleks Hillary Clinton juba president. [Ütlus reedab, et see on kirja pandud 2016. aasta USA presidendi valimiste ajal.] (14) Bosnia ilma Džekota on kui ajalugu ilma Hillar Palametsata.

(15) Aga kvaliteet, nagu võimlemise asjatundjad armastavad öelda, ei olnud just parim...

Emotsionaalse poeetilise võttena esineb hüperbool: sageli kasutab reporter mõju ja intensiivsuse saavutamiseks kõnekujundina liialdavat suurendamist (16-18).

(16) Kyle Hinesile olid need elutähtsad vabavisked.

(17) Ja sakslanna lihtsalt süüakse ära, midagi teha ei ole.

(18) Ja riputatakse Vasquez siin nüüd korralikult nöörile kuivama.

Peale objektiivselt põhjendatud seisukohtade võime muuhulgas kohata nii Eesti sportlaste ülemäärast ja kohati lausa teenimatut kiitmist (19) kui ka nende konkurentide mahategemist (19-22).

(19) Ja küll Peiffer teab, kes ta selja taga on. Kauri Kõiv ise!

(20) Ei olnud siin mingit auti, puhaku jalga slovakk!

(21) Šveitsi kaitse on nagu šveitsi juust, auklik natukene!

(22) See on käes! See on käes! See on käes! Serbia, võta välja! Võta välja, Serbia! Mine ja mängi kodus Iisraeliga! Eestist te MM-piletit ei saanud!

Emotsionaalsetes kommentaarides on sageli tuntava võttena kasutusel iroonia - peen, varjatud, kaudne pilge; kõnekujund, kus kellestki või millestki kõneldakse pilkeks teadlikult vastupidist sellele, mida mõeldakse. Sõnum on maskeeritud tõsidusega, jättes mulje tõsisest suhtlemisviisist (23-25). Iroonia on reporterite kõnekasutuses kui mänguline antidiskursus (vt ka Hutcheon 1994), et öelda välja oma seisukoht valitseva idee suhtes. Samal ajal on raske eristada tahtlikku kavatsetud irooniat ja vaataja tõlgendamisest tulenevat irooniat.

(23) Nohh, lõime värava! Kahjuks omavärava...

(24) No selge on see, et ei ole lihtne olla ilus mees. Ronaldo teab seda väga hästi!

(25) Läti on tugev hokis, Leedu korvpallis, aga Eesti? Eesti on tugev rahvatantsus... 
Ehkki kommentaatorid proovivad kohtunike tööd objektiivselt tunnustada, leiavad nad emotsiooni mõjul mõnigi kord kohtunike otsuste kirjeldamiseks sarkastilisi ja iroonilisi väljendeid (26-31). Samuti kohtab kohtunike otsuste subjektiivset hindamist (29), aga muudki aspektid võivad hakata mõjutama televaatajate eelistusi (30). Emotsionaalne foon võimaldab ütluste kaudu jälgida moraalset aspekti.

(26) Oi, ja nüüd ta on haiget saanud ju? Ja kohtunikud ei törtsuta vilet?

(27) Julm jutustamine käib täna. Nagu võrkpallikohtunikud oleks tulnud korvpalli vilistama.

(28) Siin üks pealtvaataja on nõus juba oma prille andma kohtunikele.

(29) See on selline kohtunike eputamine - vilistada just siis, kui pall õhus on.

(30) Lúcio räägib endale kollase kaardi välja. Ikka täielik tainas on see Lúcio!

(31) Selles mõttes on need Lõuna-Ameerika kohtunikud toredad, et süütenööri neil üldse polegi.

Spordireporterite tundeline kõne kajastab humoorikalt ka hinnanguid, suhtumisi, laiemalt spordiväärtusi, mida soovitakse mahlakalt ja poeetiliselt edasi anda. Näeme siin $(32,33)$, et olümpiamängud peavad kindlasti olema „tavalistest” võistlustest erinevad, kuidagi pidulikumad ning kandma teistmoodi väärtusi, mida reporterid proovivad omal moel ka esitatavasse teksti põimida (34), mõnigi kord hoopis tahtmatult huumorit luues.

(32) Loojang on juba ammu täitnud taeva ja sellele on järgnenud pilkane pimedus, kuid spordipidu Rio de Janeiros on ammugi alanud ja meie ootame pikisilmi selle lõppu.

(33) Islandlasel Jon Arnar Magnussonil endal jäi küll olümpiamedal võitmata, aga kindlasti vaatab ta uhkusega neid olümpiamänge ja seda, kuidas Eesti kümnevõistlejad astuvad olümpiastaadionile.

(34) Ja Türgiski kindlasti väärtustatakse väärtusi, mis seisnevad kiiresti pika maa jooksmises.

\subsection{Loogikahäired}

Sel tasandil peab ajakirjanik teadlikult või alateadlikult valima, kuidas ühe nalja kaks skripti omavahel ühendada (Attardo 1994: 225). Siin peetakse silmas ennekõike anekdoodile omaseid mehhanisme, nagu väärloogika ja vääranaloogia, aga ka homonüümia- ja polüseemiamängud (Attardo 1994: 225), millest tulenevad mitmemõttelisused, vasturääkivused, väärütlemised. Sellised häired juhtuvad tempoka ja sageli läbimõtlemata tekstimassiivi eetrisse paiskamisel.

Põhiliselt tekib nali ajakirjaniku väärütlemistest, nt teostamatutest mõttekäikudest (35), keeleloogika konstruktsioonide rikkumisest $(36,37)$. Vasturääkivustes esitab kommentaator tihtipeale väite ja samas lauses annab sellele vastandliku tähenduse (38-40). 
(35) Ja neile televaatajaile, kellel telereid ei ole, ütleme, et ülekannet saab kuulata ka Raadio 2-st!

(36) Poola oli teatevahetuses neljas, aga kas nüüd on Poola tõusnud seitsmendale kohale?

(37) Algamas on mängu kolmas poolaeg.

(38) Oda lendab nüüd paremini, aga kukub liiga vara maha.

(39) See on Liverpoolile raske kuu, järgmised viis või kuus nädalat.

(40) Ei ole enam palju minna, samas, oi kui palju on veel minna!

Lause tasandil kohtab paradoksi, tavakujutelmadega vastuolulisi mõtteavaldusi $(41,42)$ või oksüümoroni ehk tähenduselt vastandlikke ühendeid (43).

(41) Lund on siin tõesti palju, just nagu troopikas.

(42) Ta tahtis algul küll baleriiniks saada, aga valis lõpuks siiski vasaraheitja karjääri.

(43) Vaikus muutub üha lärmakamaks.

Loogilisele mehhanismile tuginevad polüseemilised - mitmetähenduslikud, kahemõttelised - ütlused. Sellised ütlused sisaldavad tähenduse allvorme, millele on võimalik anda erinevaid tõlgendusi ja nalja kutsub esile kuulaja mõtete liikumine vales suunas. Üldiselt tuleb see esile reporteri väljenduslaadi ebaselguses: ta võib kogemata kasutada sõnu, mida saab tajuda mitmetähenduslikena. Näites 44 suundus ilmselt sportlaste suusarada päriselt metsa, kuid televaataja tajus naljana väljendit metsa minema 'nurjuma', mis moodustas absurdse vastuolu eelnenud väitega heast stardipositsioonist.

(44) Mael on hea stardikoht, nüüd võib sõit metsa minna.

Sageli loob mitmemõttelisus seksuaalseid seoseid ja alatoone ehk huumori põhjustab kahe skripti (nt neutraalse ja seksuaalse alatooniga skripti, vt näiteid 45-50) konflikti.

(45) Näeme nüüd, et Gareth Bale on sunnitud dressipüksid jalast ära võtma, mis jalgpalliväljaku ääres tähendab ainult ühte asja. [Reporteri soov oli öelda, et mängija läheb väljakule, kuid hea tahte korral võib seda mõista mitmesugustes pikantsetes tähendustes.]

(46) Klinsmann pakub ennast väga aktiivselt. [Spordislängis tähendab väljend ennast pakkuma 'söötu otsima või küsima', televaataja mõte võib liikuda aga keha müümise radadele.]

(47) Ja näed, vanameister suudab pantrit panna küll! [Spordislängis tähendab väljend pantrit panema kaslase liikumisega sarnaneva hüppega platsile maandumist, kuid rikutud mõtlemises võib see mõjuda suguühtena sellesama kaslasega.]

(48) Suusastaadion on tehtud selliselt, et kõik naised käivad siin meie alt tiiru läbi. [Nõukogude ajast pärinev ütlus iseloomustab ajakirjanike töötingimusi suusastaadionil, kus kommentaatoriboks on püstitatud staadionile otse suusaraja kohale. 
Väljend käivad meie alt tiiru läbi on reporter öelnud otsetähenduses, kuid vaataja võib seda soovi korral mõista kui omalaadset seksuaalriituse kirjeldust.]

(49) Kuidas siin staarkommentaatorid ütlevadki - sellel mehel tuleb isegi riietusruumis peal olla! [Reporter kirjeldab tugevat kaitsemängu, ent seda saab ka mõista kui vihjet meestevahelisele armastusele, mis leiab oma lõpliku väljundi duširuumis.] (50) Orienteerumine on sellepärast tore, et siin saavad ka vanemad mehed ja naised selle asja metsa vahel nii ära õiendada, et keegi pealt ei näe. [Nõukogudeaegne kild, milles selle asja ära õiendamine omas reporteri mõttes ilmselgelt tähendust 'sportimine', vääranaloogias viitab see võimalusele, et metsaalune on eakamatele inimestele sobiv ja piisavalt varjuline paik suguliseks läbikäimiseks.]

Naljakad on ühiskondlike tabudega (nt alkoholitarbimine) seostatavad mitmemõttelisused: näites 51 liigub ajakirjaniku mõte ilmselt joogipunktis alkoholivaba vedeliku tarbimisele, näites 52 viitab sportlase kainele mõistusele suusatamise strateegia valikul, kuid kahemõttelisus loob kuulajates kujutluspildid seoses alkoholitarbimisega. Ütluses 53 tekitab huumori mitmemõtteline fraas on täiesti täis tähendustes 'on alkoholijoobes' ja 'on rahvast täis'. Tabudega seotud huumori allrühma kuuluvad ka kommentaatorite süütuna mõeldud lausungid, mis assotsieeruvad kehaliste esmavajadustega $(54,55)$.

(51) Mehed hakkavad juba esimesel ringil jooma.

(52) Ja Aivar Rehemaa on sõitu alustanud kainelt.

(53) Siin paluti vähemalt kaks tundi varem kohale tulla ja see on ka põhjus, miks tribüünid on juba täiesti täis.

(54) Püsti laskmine ei ole lihtne.

(55) Miks mäng seisab? Aa, tundub, et keegi on väljaku nurgas pattu teinud!

\subsection{Lingvistilisel ressursil põhinevad sõna- ja lausetasandi naljad}

See kategooria hõlmab eelkõige lingvistilise tasandi leksikaalsed, süntaktilised, fonoloogilised jm valikud, mille põhjal tekivad ajakirjaniku kõnes tahtmatud sõnamängud, ootamatud kõnekujundid, parasiitväljendid, tuntud ütluste või tüvitekstide edasiarendused, vanasõnade, tsitaatide uuskasutus. Enamasti tekib siin nali sõna tasandil: polüseemia ehk mitmetähenduslikkus kutsutakse esile homonüümia (56) ja sarnassõnade ehk paronüümia $(57,58)$ või malapropismi $(59)$ abil. Palju kohtab kalambuuritsemist sportlaste nimede ümber $(60,61)$; nalja võib põhjustada võõrapärase nimega sportlane, kelle nimel on eesti keeles pikantne tähendus (62).

(56) Lahtis on lahtist lund, aga iseenesest pole midagi lahti. [Tähistajale lahti vastab kolm üksteisega seotud tähistatavat: Lahti Soome kohanime ja võistluspaigana, lahti kui millestki vaba ja lahti kui väljendi pole midagi lahti tähenduses 'midagi pole juhtunud.]

(57) Staadionil pandi lehvima Eesti trikoo. [pro trikoloor]

(58) Ta libestab ennast sinna täpselt õigel hetkel. [pro libistama]

(59) Publik tsiteerib: „Rossija, Rossija!” [pro skandeerib] 
(60) Martin Jaks on oma jaksu kõik rajale kulutanud.

(61) Ei ole seda tavalist vunki täna mängus sees. [vunk 'hoog, teravus, särtsakus'vs. jalgpallur nimega Martin Vunk.]

(62) Brasiillane Kaka on palliga. Tihti ei saa tema nime kasutada, kuna nimi lõikab kõrva.

Reportaažile omases kiirkõnes juhtuvad tihti alateadlikult keelevääratused. Sageli kuuleme keeles olematute sõnade hääldamist, mida tehniliselt ei saa paronüümseks/ homonüümseks nimetada $(63,64)$. Segiajamisest võib tuleneda humoorikaid spoonerismilaadseid üksusi $(65,66)$. Humoorikalt võivad mõjuda kõige tavalisemad grammatilise ühildumise vead $(67,68)$. Esineb ka teatud konkreetsete konstruktsioonide, nt reportaaži avatervituste, süstemaatilist segiajamist $(69,70)$, kuigi on välja toodud (nt Susi 2019: 116), et eesti reporterite sissejuhatused enne avavilet erinevad reportaaži põhiosast korrektsete ja läbimõeldud lausete ja väljendite poolest, on asjalikud ja objektiivsed, kuna on enne valmis kirjutatud. Spordikommentaatorid eksivad ka mitmesõnaliste kinnisväljendite sõnajärjes (71).

(63) Ka järgnevad kohad lähevad keenlannastele. [pro keenialannadele]

(64) Keenlannade käes on kuusikjuhtimine. [pro kuuikjuhtimine]

(65) Ja nüüd on aeg veidi sooladele haavu raputada. [pro haavadele soola]

(66) Solemdal vahendas vähet. [pro vähendas vahet]

(67) Olümpiakülast palju pole sportlastel siia sõita sellesse areenile.

(68) Hästi seal Thomas Heurtel mööda seal selle viske paneb.

(69) Tere õhtust, kallid spordiuudised!

(70) Lugupeetud raadiovaatajad!

(71) Tõusva maa päikese [pro tõusva päikese maa] pojad Jaapanist on Tallinnas haruldased külalised.

Võrreldes ohtra ja mahlaka väljendikasutusega, nt äärmiselt rikkaliku ja originaalse võrdlusmaterjaliga, on segiajamisel ja keelevääratustel põhinevaid nalju siiski vähe. Põhjus võib olla subjektiivne: sellised lihtsakoelistel vigadel ja eksimustel põhinevad naljad on tundunud kirjapanijale vähempõnevad (ja lähenevad pigem tähenärimisele) kui mahlakat ja vaimukat väljenduslaadi sisaldavad ütlused.

Lingvistilisse naljarühma saame paigutada sisutühjad ja parasiitväljendid, mis on osa ajakirjaniku idiolektist. Pikaaegsed spordisõbrad oskavad kindlatelt ajakirjanikelt oodata neile iseloomulikke väljendeid (kommentaatorite tüüpilistest parasiitväljenditest või idiosünkraasiatest vt nt Susi 2019: 122). Siinne uurimus jätab konkreetsete ajakirjanike eriomase keelekasutuse vaatlemata.

Lause tasandil esineb ilmselt n-ö eetri täitmise vajadusest tingitud akumulatsiooni ehk kuhjamist, kus mõnd vormivõtet korratakse kaks või enam korda (72-76).

(72) Aga karunahka ei saa veel jagada, sest karu alles sõidab metsas. See on Lukas Baueri nimeline karu.

(73) Millegipoolest meenutab see jaapanlannast judoka minu naist. Aga ainult millegipoolest... 
(74) Nii kummaline, kui see ka ei ole, oleme me täna kuulnud igasugu kummalisi helisid. Aga missugune päev tuleb homme, seda saame tõesti teada homme.

(75) Tora Bergeril oli vist üks eksimus, kui ma nüüd ei eksi.

(76) Kittel on Kittel! No on Kittel tõesti! Temale kitli peale anda ei suutnud sprindifinišis keegi. [Saksamaa jalgrattur Marcel Kittel on eriti tugev just finišispurdis.]

Tihtipeale kõlavad naljakalt tähenduseta ütlused, mis suulises reportaažis võivad juhtuda lihtsalt vajadusest aeg täis rääkida (77-79). Iseloomulik on üldistavate sõnade, asesõnade ning aja- (täna, homme) ja kohamääruste (siin) tarvitamine. Niisiis kuuluvad sellesse kategooriasse käibetõdede korrutamine, elementaarsused, mõttekordused, mittemidagiütlemised - rääkimine eesmärgiga lihtsalt midagi rääkida, sest ajakirjanik või ekspert ei või võistlust kommenteerides vait olla. Joosep Susi (2019: 122) on nimetanud primitiivsuste ilmnemist ja klišeedest kubisevat poeetikat ametlikuks spordilobaks (80-86).

(77) No me rääkisime, et siin võib mis iganes juhtuda, ja nii see juhtuski. No me ei tea, mis täpselt juhtus. [Rikutud ka loogilist struktuuri - üks väide lükkab teise ümber.]

(78) Selliseid asju peavad hispaanlased rohkem tegema, kui nad soovivad olla selles edukad.

(79) Vaheajal räägiti riietusruumis seda, et vaadates tabloole on seis selline, nagu ta on...

(80) Pall on tõesti ümmargune, kinnitame meie siit targa näoga juurde.

(81) Tee, mida sa teed, sport jääb spordiks.

(82) Vise tuleb välja, aga ei lähe sisse.

(83) 87:72 - see on hoopis midagi muud 84:72! Ma usun, te nõustute minuga?

(84) Minu arvates on tänane mäng järjekordne näide sellest, et need tulemused, mis tehakse valiksarjades, maksavad ainult niipalju, et siia finaalturniirile pääseda.

(85) See meeldis kaasaelajatele ja nad hakkasid oma meeskonnale kaasa elama.

(86) Löök läheb üle lati ja vist ka mööda!

Sõna- ja lausetasandi naljadena saab käsitleda tuntud ütluste, vanasõnade, kultustsitaatide vmt sihiteadlikku või kogemata juhtunud parafraseerimist. Modifitseerides ja parafraseerides varasemaid kultuuritekste, toetuvad ajakirjanikud nn jagatud kultuuripagasile. James V. Wertsch (2002: 120) on nimetanud selliseid kultuurinähtusi mingi kogukonna (siin eestlaste) kollektiivses mälus paiknevateks tekstiressurssideks, mille hulka kuuluvad ühiskonnas tuntud tuumtekstid, nt nii pärimuskultuur (vanasõnad, kõnekäänud vms) kui ka kirjandus(klassika) ja kooliõpikutes kirjapandu ning kõnealuste tsitaatide näitel kultuuriruumis levinud muusika (laulusõnad), filmid, reklaamid ja massimeedia. Ütlustes kohtame põlvkondade kaupa tuttavat kirjandus- ja filmiklassikat (87-93); tsitaatide allikaks võivad olla ka tuntud laulud (94).

(87) Vunk virutab südamest. Aga väga õige! Mis kinni ei jää, saab kinni löödud! [Oskar Lutsu „Kevade”.] 
(88) Mis kinni ei jää, saab ikkagi sisse visatud! [„Kevade”.]

(89) Jasikevicius näitab, et mis te ootate, rünnakule! Edasi, Kentuki poisid! [„Kevade”.]

(90) Head televaatajad, see on finaal! Kellele lilled, kellele heinamaa, kellele päikesepaiste! [„Kevade”.]

(91) Jah, nüüd võib siis Šveits öelda, et kui seda Metsa ees ei oleks... [Juhan Liivi „Vari”, tsitaadis tekib polüseemia sportlase nimega Mets.]

(92) Seal on lobisemist üldse palju, aga meil ju lobisemise eest palka ei maksta. Meil makstakse jooksmise eest. [Mängufilm „Viimne reliikvia”.]

(93) See mäng on nagu Piibeleht - kord on üks all ja siis teine all. [Eduard Vilde „Pisuhänd”.]

(94) Ei hõbedat, kulda ei leidu sel maal ega ka ühtegi pronksi. Loodetavasti siis viljakandvat mulda? [Martin Körberi laul „Mu isamaa armas”.]

Spordireporterite rohke vanasõna- ja väljendikasutus suulises reportaažis kinnitab ajakirjanike head teadmust, kuid vanasõnu mitte lihtsalt ei kasutata, vaid neid ka modifitseeritakse $(95,96)$ ja parodeeritakse $(97,98)$ ning saadud uudne tulemus mõjub tujutõstvalt.

(95) Karavan on haukunud, koerad liiguvad edasi. [Las koerad hauguvad, karavan liigub edasi.]

(96) Parem punkt peos kui tuvi katusel! [Parem varblane peos kui tuvi katusel.]

(97) Kus viga näed laita, seal punasega tule ja aita - see on selle türklase tänane töökeel. [Vanasõnasse Kus viga näed laita, seal tule ja aita on kohandatud jalgpallikohtunike töövahend punane kaart, mis tähendab mängija eemaldamist.]

(98) Tegijal juhtub, aga meeskonnal sellest kergemaks ei lähe. - Jah, päevad pole vennad ega ööd pole... Ööd pole õed! [Reporteri ja eksperdi lühidialoogis on lausa mitu vanasõna: esimest - Tegijal juhtub - on kasutatud klassikalisel kujul, teisel juhul hakkab dialoogipartner edasi arendama vanasõna Aastad pole vennaksed, asendades aastad päevadega ja esitades parallelistliku mõttekordusena vanasõna Ööd pole õed.]

\section{Kokkuvõte}

Uurimismaterjalina on spordikommentaatorite keelekasutus tänuväärne allikas lingvistidele, folkloristidele, kultuuriuurijatele. Aines reedab, millised on ajakirjaniku ettekujutused kuulajate-vaatajate eelistustest, olles samal ajal teejuht päevakajaliste spordisündmuste juurde.

Narratiivne tegevuse kirjeldus on sel lühifolkloori vormil napisõnaline või puudub üleüldse, reporteri ütlus sisaldab ühtlasi koomilist efekti põhjustavat puänti. Spordikommentaatorite ütlused võivad tuntud käibefraasidena folkloriseeruda. Tegemist on keelenaljadega, mistõttu on parim viis neid käsitleda verbaalse huumori üldteooria valguses.

Oleme siinses käsitluses keskendunud just lingvistilisele ja loogiliste mehhanismide tasandile, lisades neile reportaažižanrile iseloomuliku emotsionaalsuse fooni kui huumori tekkes olulise kontekstuaalse faktori. Introspektiivselt näitab analüüsitav aines 
ennekõike seda, mis on tundunud ühele kogujale naljakas ja väärinud üleskirjutamist. Kogumisväärseks teeb ütluse selle naljakus, emotsionaalne üllatus, mis tekib ootamatult reportaaži jälgimisel. Käesoleva materjali põhjal otsustades vallandab huumori tekkeks vajaliku üllatusmomendi ootamatu, tavapärasest erinev loogika, asjadest omamoodi arusaamine, vääritimõistmine, keelevääratused, edasiarendused, mis tunduvad teatud situatsioonis või per se vaimukad, huvitavad, olles emotsionaalselt väärt jäädvustamist ja edasirääkimist. Vasturääkivused, liialdused, alateadlikud eksitused, ehe ja siiras otsekohesus erinevad tihtipeale traditsioonilisest kõnepruugist ja mõjuvad üllatuslikult. Humoorikuses mängivad rolli enim sõna- ja lausetasandi mehhanismid, kõnekujundeist suurima osa moodustavad sidesõnadega nagu ja kui algavad võrdlused (üle 20\% kogu 2000-tekstilisest korpusest), mille siht on väljendada ja kirjeldada mingi omaduse intensiivsust. Ajakirjaniku originaalsus on piltlikke, kohati absurdseid võrdlusi esitades piiramatu. Sellisest originaalsusest, võrdlusobjekti ja võrdlusaluse pealtnäha sobimatus ja tarbija jaoks ootamatus kokkupanekus sünnibki nali.

Ainest süstematiseerides ilmnevad teatud tendentsid, kattuvad kategooriad. Emotsionaalse üldtonaalsuse järgi saab eristada ehedat võidurõõmu, aga ka traagilist kaotusekibedust kajastavat huumorit, mis väljendub mahlakas ja kohati absurdile üles ehitatud kujundiloomes ning kasutab nt üht fraseologismide levinumat alaliiki - võrdlusi. Osa ütlusi on üles ehitatud loogikahäiretele, mis väljenduvad nt paradoksides, oksüümoronis. Puhtkeeleliste tehnikate järgi sünnib huumor kas sõna- või lausetasandil, nt paronüümsete, homonüümsete mitmemõttelisuste abil. Sihtmärgina esinevad naljades enamasti nii sportlane, kohtunik kui ka treener, kuid võib kohata ka juhuslikke objekte publikust kuni täiesti spordiväliste osalejateni.

Spordikommentaatorite ütlusnaljade kogu on killuke spordiajalugu, omamoodi kõverpeeglis. Lõpuks polegi tähtis, kes mida ütles, vaid tähtis on sealt saadav emotsioon: mida öeldi, mida mõeldi ja miks see naljakas võis tunduda. See on meie spordiajalugu peegeldav paljupalgeline kultuurinähtus, mida on edaspidi võimalik analüüsida väga erinevatest vaatenurkadest. Eraldi süüvimist värivad mitmed kujundkõne aspektid (nt iseseisev suur allrühm võrdlused), aga võimalik on korpust käsitleda nt spordiajaloolisest, soouurimuslikust, sotsiokultuurilisest vaatenurgast.

Autorite siiras tänu ja lugupidamine kuuluvad kõigile spordiajakirjanikele, kes tihti lii-
gagi karmist spordisõprade kriitikast hoolimata oma rasket ametit peavad ja kelleta
poleks teema käsitlemine võimalik. Lisaks kuulub autorite eriline tänu artikli anonüüm-
setele retsensentidele kõigi asjakohaste märkuste-soovituste eest. Kirjutis on seotud
Eesti Teadusagentuuri uurimisprojektiga IUT22-5 „Folkloori narratiivsed ja usundilised
aspektid", selle valmimist toetas Euroopa Liit Euroopa Regionaalarengu Fondi kaudu
(Eesti-uuringute Tippkeskus).

ARHIIVIALLIKAD

Eesti Kirjandusmuuseumi folkloristika osakonna teadusarhiiv EFITA (F02-016-0001). 


\section{VEEBIVIITED}

Delfi Sport 2019. „Elämä on laiffi” ja teised Matti Nykäneni paremad tsitaadid. https:// sport.delfi.ee/news/melu/uudised/elama-on-laiffi-ja-teised-matti-nykaneni-paremadtsitaadid?id=85220535 (5. I 2020).

Facebook: Kalev Kruusi parimad palad. https://www.facebook.com/kruusinaljad/ (1. IX 2019).

Facebook: Kalev Kruus tsitaadid. https://www.facebook.com/Kalev-Kruus-tsitaadid201115846633967/ (1. IX 2019).

\section{KIRJANDUS}

Attardo, Salvatore 1994. Linguistic Theories of Humour. Berlin-New York: Mouton de Gruyter.

Attardo, Salvatore 2010. A primer for the linguistics of humor. - The Primer of Humor Research. (Humor Research 8.) Toim Victor Raskin. Berlin-New York: Mouton de Gruyter, lk 101-155.

Attardo, Salvatore; Raskin, Victor 1991. Script theory revis(it)ed: joke similarity and joke representation model. - Humor. International Journal of Humor Research, kd 4, nr 3-4, lk 293-347.

Brady, Adrian 2012. Opening His Legs and Showing His Class: The Funniest and Daftest Sports Quotes Ever. Welbeck Publishing Group.

Chovanec, Jan 2016. Eavesdropping on media talk: Microphone gaffes and unintended humour in sports broadcasts. - Journal of Pragmatics, kd 95, aprill, lk 93-106.

Ferguson, Charles A. 1983. Sports announcer talk: Syntactic aspects of register variation. Language in Society, kd 12, nr 2, lk 153-172.

Harrik, Airika 2020. Sünnituskohaga ei mangita! Skandaalse uudise vastuvõtt Facebooki grupis KalambuuR. - Keel ja Kirjandus, nr 1-2, lk 30-43.

Hutcheon, Linda 1994. Irony's Edge: The Theory and Politics of Irony. London-New York: Routledge.

Kalenjuk 2019 = E. Kalenjuk (koost). Ja - kommentator! Vasilij Utkin, Viktor Gusev, Vladimir Stognienko, Gennadij Orlov, Oleg Žolobov, Ol’ga Bogoslovskaja i drugie o tonkostjah professii. Moskva: Èksmo. [Э. Каленюк (ред.), Я - комментатор! Василий Уткин, Виктор Гусев, Владимир Стогниенко, Геннадий Орлов, Олег Жолобов, Ольга Богословская и другие о тонкостях профессии. Москва: Эксмо.]

Krikmann, Arvo 2004. Koestler, Raskin, Attardo ja teised. Lingvistiliste huumoriteooriate uuemaist arenguist. (Reetor 4.) Tartu: Eesti Kirjandusmuuseum.

Laineste, Liisi 2003. Suunad huumori uurimises. - Keel ja Kirjandus, nr 11, lk 793-804.

Liik, Peeter 2013. Televisiooni spordireportaažidele iseloomulikud jooned Eesti, USA ja Briti ajakirjanduspraktikas. Magistritöö. Tartu: Tartu Ülikooli sotsiaal- ja haridusteaduskond, ajakirjanduse ja kommunikatsiooni instituut. http://hdl.handle.net/10062/31122

Müller, Torsten 2007. Football, Language and Linguistics: Time-critical Utterances in Unplanned Spoken Language, Their Structures and Their Relation to Non-linguistic Situations and Events. Tübingen: Gunter Narr Verlag. 
Nilsen, Alleen Pace; Nilsen, Don L. F. 2000. Encyclopedia of 20th-century American Humor. Phoenix: Oryx Press.

Raskin, Victor 1985. Semantic Mechanisms of Humor. (Synthese Language Library 24.) Dordrecht-Boston-Lancaster: Reidel \& Hingham.

Rebane, Raul; Tammaru, Tõnu 2010. Kilde ETV spordireportaažidest. - Uba. Toomas Uba. Koost Gunnar Press, Voldemar Lindström. Tallinn: Menu Kirjastus, lk 49.

Steen, Rob 2008. Sports Journalism: A Multimedia Primer. London-New York: Routledge.

Susi, Joosep 2019. Kadunud poeetika otsinguil. Ühe jalgpallireportaaži arvustus. - Vikerkaar, nr 4-5, lk 113-124.

Uba, Toomas 1968. Spordireportaaž raadios ja televisioonis. - Fakt. Sõna. Pilt. Kd IV. Tartu: Tartu Riiklik Ülikool, lk 118-177.

Voolaid, Kalle 2010. Mootorratturid tulevad kurvist, Till pikalt ees! Tallinn: Jutulind.

Voolaid, Kalle 2015. Mootorratturid tulevad kurvist, Till pikalt ees! 2. Tallinn: Jutulind.

Voolaid, Piret 2015. Lapsesuufolkloor lingvistilise huumoriteooria vaateväljas. Suulistel ütlustel põhinev kirjalik traditsioon. - Keel ja Kirjandus, nr 12, lk 841-858.

Wertsch, James V. 2002. Voices of Collective Remembering. Cambridge: Cambridge University Press.

Williams-Smith, Jake 2019. Murray Walker: I wouldn't be here if social media existed in my time. - MotorSport, 30. VII. https://www.motorsportmagazine.com/news/f1/ murray-walker-i-wouldnt-be-here-if-social-media-existed-my-time?fbclid=IwAR2 I09CeUEW65EGAoxGgfsFT-pyPZ8W_9C1dGu6z3wBoxsbBgz1GzpWIN4 (1. IX 2019).

Õim, Katre 2003. Võrdluste struktuurist ja kujundisemantikast. (Reetor 2.) Tartu: Eesti Kirjandusmuuseum.

Piret Voolaid (snd 1971), PhD, Eesti Kirjandusmuuseumi vanemteadur, Eesti-uuringute Tippkeskuse tegevjuht (Vanemuise 42, 51003 Tartu), piret.voolaid@folklore.ee

Kalle Voolaid (snd 1969), MA, Eesti Spordi- ja Olümpiamuuseumi teadur (Rüütli 15, 51007 Tartu), kalle.voolaid@spordimuuseum.ee

\section{Sport commentators' gaffes as a source for folk humour}

Keywords: folklore, humour, linguistic theories of humour, sport commentators' bloopers, sport commentators' gaffes, sport commentators' use of language

The paper analyses, from folkloristic and humour theoretical aspects, sports commentators' gaffes, or bloopers, collected from live sports broadcasts on different Estonian media channels from 2010-2019. We will attempt to answer three questions: 1) How should such comments be defined in terms of folklore? 2) Which theoretical humour mechanisms are the foundation of this humour? 3) How to categorise the gaffes? 
The main focus of the article is on gaffes as a subtype of humor. Sports commentators' gaffes fall into the category of linguistic humour, which is why it can be analysed by means of linguistic theories of humour. Although we may suspect that sports journalists are intentionally funny, it is generally not true. The remarks are usually not funny for the commentators themselves, but the audience perceive the jokes emerging during live broadcasts as unintentional humour (see Martin 2007) or accidental humour (Nilsen, Nilsen 2000). Sports commentators' gaffes can be adequately researched in light of the General Theory of Verbal Humour (GTVH) by Salvatore Attardo and Victor Raskin (1991), which generally uses the hierarchic representation model of six knowledge resources. What makes these cases worth recording is their juicy expressiveness, different logic, mistakes, developments that seem interesting and emotionally valuable. The material has a great potential of becoming folklore, starting a life of its own among people, losing the initial connection with the author of the gaffe. It can also be seen as a phenomenon reflecting Estonian sports history. This survey is an attempt to categorise the material in terms of GTVH: tautologies, unintentional juxtapositions where the viewer/listener knows what is meant, nonsense, pointless words, unintended puns, reuse of old proverbs etc. Of course, one has to keep in mind that we can usually not speak of intentional linguistic 'comedy' in the case of this kind of jokes, which is why the gaffes should better be described with neutral linguistic terms (metathesis, paronymy, homonymy with its subtypes of homography and homophony) instead of intentional types of humour (wordplay, such as spoonerism, malapropism, Freudian slip, paranomasia/ paranomastic image).

Most of the relevant mechanisms function at word and sentence levels. Most of the tropes in our collection are similes with comparative conjunctions such as $n a g u$ and $k u i$ (over $20 \%$ of the 2000 -strong corpus), used to express and describe the intensity of a property. There is no limit for a journalist producing figurative, sometimes quite absurd similes, while humour is born from the seeming incongruence of the subject and the referent of comparison taking the recipient by surprise.

Piret Voolaid (b. 1971), PhD, Estonian Literary Museum, Senior Research Fellow; Executive Manager of the Centre of Excellence in Estonian Studies (Vanemuise 42, 51003 Tartu), piret.voolaid@folklore.ee

Kalle Voolaid (b. 1969), MA, Estonian Sports and Olympic Museum, Researcher (Rüütli 15, 51007 Tartu), kalle.voolaid@spordimuuseum.ee 